Rivan Wibowo

Vol. 3 No 1, Februari 2021

ISSN 2657-0203

e-ISSN 2686-0244

\title{
PROFIL DESA BERKELANJUTAN DI DESA KARANG MULYA, KECAMATAN TELUK JAMBE BARAT, KARAWANG
}

\author{
Rivan Wibowo \\ Universitas Buana Perjuangan \\ Akuntansi, Fakultas Ekonomi dan Bisnis, UBP Karawang \\ rivanwibowo@ubpkarawang.ac.id
}

\begin{abstract}
ABSTRAK
KKN merupakan kegiatan pengabdian kepada masyarakat di daerah tertentu atau lembaga pendidikan, dilaksanakan secara kelompok, terintegrasi antar jurusan, terkoordinasi di tingkat Fakultas, Kegiatan KKN (Kuliah Kerja Nyata) dilakukan secara online yang bertujuan untuk memberikan pengalaman kerja nyata di lapangan dalam bidang apapun yang membentuk sikap mandiri dan tanggung jawab dalam pelaksanaan pekerjaan di lapangan. KKN juga bertujuan untuk membantu masyarakat dalam meningkatkan pengetahuan dan keterampilan sehingga diharapkan dapat meningkatkan kesejahteraannya. Kegiatan KKN dibagi menjadi empat tahap kegiatan, yaitu pembekalan, pelaksaaan kegiatan secara daring agar dapat mencegah penyebaran COVID-19 dan penyusunan laporan, dan evaluasi. Pelaksanaan KKN ini dimulai dari tanggal 1 agustus 2020 sampai dengan 31 Agustus 2020 di Desa Karangmulya Kecamatan Telukjambe Barat Kabupaten Karawang. DesaKarang Mulya merupakan salah satu desa yang berada di Kecamatan Teluk jambe Barat.Yang letak geografisnya dekat sekali dengan kota Karawang. Sebagian besar penduduknya bermata pencaharian sebagai petani,ada juga yang berprofresi sebagai guru ,home industry,dan juga berdagang. Kondisi perekonomian masyarakat pada umumnya mengandalkan pertanian.

Desa Karang Mulya terletak sangat dekat dengan Kantor Kecamatan Telukjambe Barat,jika ditempuh dengan memakai kendaraan dapat menghabiskan waktu selama \pm 10 menit menggunakan kendaraan bermotor.

Jumlah luas tanah DesaKarang Mulya seluruhnya mencapai 425,0000 ha dan terdiri dari tanah darat dan tanah sawah. Wilayah Desa Karang Mulya yang beriklim tropik basah memiliki curah hujan sebesar 200-300mm per tahun. Iklim di Desa Karang Mulya terdapat dua musim yaitu musim hujan dan musim kemarau.Musim hujan terjadi pada bulan November hingga Mei.Sedangkan musim kemarau umumnya terjadi pada bulan Juni sampai Oktober. Desa Karang Mulya memiliki intensitas curah hujan sedang sehingga suhu udara tinggi dan kategori ini cukup baik untuk dapat mendukung kegiatan masyarakat dalam bidang pertanian. Sumber air yang digunakan oleh warga Desa Karang MulyaKecamatan Telukjambe Barat untuk keperluan sehari-hari adalah sumur gali dan air pam.
\end{abstract}




\title{
Rivan Wibowo \\ Vol. 3 No 1, Februari 2021 \\ ISSN 2657-0203 \\ e-ISSN 2686-0244
}

Kata Kunci : KKN, Karangmulya, Telukjambebarat

\begin{abstract}
$K K N$ is a community service activity in certain areas or educational institutions, carried out in groups, integrated between departments, coordinated at the Faculty level, KKN activities (Real Work Lectures) are carried out online which aims to provide real work experience in the field in any field that forms independent attitude and responsibility in carrying out work in the field. KKN also aims to assist the community in increasing knowledge and skills so that it is expected to improve their welfare. KKN activities are divided into four activity stages, namely provisioning, implementing online activities so as to prevent the spread of COVID-19 and compiling reports, and evaluating. The implementation of this Community Service Program starts from August $1^{\text {st }} 2020$ to August 31th 2020 in Karangmulya Village, Telukjambe Barat District, Karawang Regency. Karang Mulya Village is one of the villages located in Telukjambe Barat Subdistrict, which is geographically very close to the city of Karawang. Most of the population works as farmers, some are teachers, home industry, and also trade. Generally, the economic condition of the people relies on agriculture.

Karang Mulya Village is located very close to the Teluk Jambe Barat District Office, if it is reached by using a vehicle it can take \pm 10 minutes using a motorized vehicle.

The total land area of Karang Mulya Village reaches 425,0000ha and consists of overland land and paddy fields. The area of Karang Mulya Village, which has a wet tropical climate, has rainfall of 200-300mm per year. The climate in Karang Mulya Village has two seasons, namely the rainy season and the dry season. The rainy season occurs from November to May. Meanwhile, the dry season generally occurs from June to October. Karang Mulya Village has moderate rainfall intensity so that the air temperature is high and this category is good enough to be able to support community activities in agriculture. The water sources used by the people of Karang Mulya Village, Teluk Jambe Barat Subdistrict for their daily
\end{abstract}

Keywords: Real Work Lecture, Village Profile, Village Potential 
Rivan Wibowo

Vol. 3 No 1, Februari 2021

ISSN 2657-0203

e-ISSN 2686-0244

\section{PENDAHULUAN}

Sebagai sebuah Perguruan Tinggi, Universitas Buana Perjuanga Karawang (UBP Karawang) wajib melaksanakan Tri-Dharma Perguruan Tinggi. Tri-Dharma yang dimaksud adalah melaksanakan Pendidikan, Penelitian, dan Pengabdian kepada Masyarakat sebagaimana tertuang pada Undang-Undang RI Nomor 12 Tahun 2012 tentang Pendidikan Tinggi. Salah satu bentuk Pengabdian kepada Masyarakat oleh dosen dan mahasiswa adalah dengan pelaksanaan kegiatan Kuliah Kerja Nyata (KKN).

Kuliah Kerja Nyata merupakan proses pembelajaran bagi mahasiswa S1 Universitas Buana Perjuangan Karawang yang dikembangkan melalui kegiatan pengabdian kepada masyarakat dalam berbagai segi

kehidupan bermasyarakat.

Pelaksanaan KKN ditujukan untuk menumbuh kembangkan empati dan kepedulian civitas akademika UBP terhadap (1) berbagai permasalahan yang riil dihadapi masyarakat dan (2)

pembangunan berkelanjutan yang diperlukan untuk mencerdaskan kehidupan bangsa dan mewujudkan kesejahteraan masyarakat yang sesuai dengan sebenar-benarnya.

Di UBP Karawang, sesuai dengan Panduan Akademik UBP Karawang Tahun 2020, ditetapkan bahwa pelaksanaan KKN bersifat wajib bagi seluruh mahasiswa dengan bobot 3 SKS

yang dilaksanakan setelah menempuh minimal 100 SKS

pada semester 7. UBP Karawang telah dua kali sukses

menyelenggarakan kegiatan $\mathrm{KKN}$ yaitu KKN Tematik tahun 2018 dengan peserta sebanyak 855 mahasiswa dan KKN Tematik Citarum Harum 2019 dengan peserta sebanyak 1082

mahasiswa. Pada KKN 
Rivan Wibowo

Vol. 3 No 1, Februari 2021

ISSN 2657-0203

e-ISSN 2686-0244

sebelumnya, mahasiswa di tempatkan di desa-desa di berbagai kecamatan di Kab.

Karawang. Kegiatan ini mendapatkan apresiasi yang positif dari Pemerintah Kab. Karawang dan masyarakat karawang terutama yang di

lokasinya ditempatkan mahasiswa mahasiswi KKN.

Dengan kata lain, melalui KKN ini, berkaitan dengan kondisi saat ini dimana permasalahan kesehatan yang sudah ada beberapa bulan terkhir yaitu adanya Corona virus. Dengan ini Tim KKN

karangmulya membantu

melakukan pencegahan penyebaran virus corona dengan

memberikan sabun untuk mencuci tangan. Selain itu Tim KKN Karangmulya membantu perihal kebersihan Kantor desa dengan membuatkan Tempat sampah di sekitar Kantor Desa.

Dalam konteks KKN online tahun 2020, hanya 4 tujuan saja yang akan diangkat untuk dikaji di tingkat desa yaitu:

1. Desa Karangmulya tidak memiliki banyak Badan

UsahaMilikDesa

(BUMDes).Desa

Karangmulya hanya memiliki 1(satu) BUMDes ialah penyewaan mesin perontok padi.

2. Belum tercapai sepenuhnya Alokasi Dana Desa dalam pemberdayaan masyarakat

3. Penggunaan media online yang belum optimal sebagai bahan ajar anak - anak sekolah pada masa pandemi

4. Hasil pertanian padi yang tidak stabil sehingga membuat harga jual ikut serta tidak stabil dan berpengaruh terhadap penghasilan masyarakat

\section{METODE}

Dengan mewabahnya Virus

COVID-19 maka Pembatasan 
Rivan Wibowo

Vol. 3 No 1, Februari 2021

ISSN 2657-0203

e-ISSN 2686-0244

Sosial Berskala Besar adalah

salah satu cara untuk membatasi

aktivitas masyarakat untuk tidak

berkerumun,

menerapkan

physical distancing dan harus

tinggal di rumah guna memutus

mata rantai penyebaran virus

tersebut. Kebijakan yang

diterapkan tersebut akan

mengubah semua aktivitas

keseharian warga dan sendi-

sendi kehidupan manusia

Kegiatan wajib Kuliah Kerja

Nyata (KKN) pada tahun 2020

ini menggunakan metode yang

berbeda yaitu secara on line bila

dibandingkan dengan

tahun

tahun sebelumnya

dimana

caranya dengan

menerjunkan

mahasiswa ke

desa-desa.

Sehingga terdapat

perubahan

mekanisme pelaksanaan

KKN tahun

2020

KKN.

ini

dilaksanakan

secara

online

dengan memanfaatkan

teknologi informasi

komunikasi, koordinasi

pengambilan data.

media

untuk
HASIL DAN PEMBAHASAN

Karangmulya adalah desa di kecamatan

Telukjambe

Barat,

Kabupaten

Karawang,Masyarakat

Desa Karangmulya mayoritas bermata

pencaharian sebagai petani,hal ini didukung oleh kondisi geografis desa

yang terdapat banyak sawah dengan

sistem

pengaiaran yang mudah

dijangkau.

Wilayah

Desa Karangmulya

merupakan

wilayah yang terbuka

dalam arti tidak terisolir,hal ini dapat

dilihat dari lancarnya akses keluar dan

masuknya ke Desa Karangmulya,Desa

ini dapat dikatakan desa yang cukup

maju,dengan melihat kondisi desa yang tidak jauh dari pusat kota

Karawang.desa Karangmulya sendiri

memiliki stuktur desa

$45 \%$

Pertanian, $10 \%$ industri dan $45 \%$

pemukiman penduduk,maka dapat

dikatakan Desa Karangmulya desa

yang berpotensi maju dalam bidang

pertanian

dan

bahkan

ada

kemungkinan

berpotensi juga

di

dan bidang sektor industri.

Kondisi tersebut diatas

tidak

dibarengi dengan optimalnya Alokasi 
Rivan Wibowo

Vol. 3 No 1, Februari 2021

ISSN 2657-0203

e-ISSN 2686-0244

Dana Desa yang seharusnya untuk membuat kemajuan bidang pertanian untuk menstabilkan harga dan memaksimalkan Badan Usaha Unit Desa agar dana bias berputar kembali serta penggunaan media online agar pola pendidikan anak dimasa pandemi.

Dalam mengatasi permasalahan tersebut diantaranya yaitu :

1. Diketahui bahwa pada periode sebelumnya Desa Karangmulya memiliki BUMDes lainnya seperti peternakan milik desa dan koperasi. Tetapi BUMDes tersebut tidak bisa bertahan lama. Diduga gagalnya program kerja ini dikarenakan kurangnya kesadaran masyarakat atas kewajibannya, kurangnya kemampuan masyarakat dari segi ekonomi, kurangnya inovasi untuk maju, juga sumber daya manusia yang kurang memadai dalam mengelola Badan Usaha Milik Desa (BUMDes) tersebut.

. Untuk mengatasi kondisi tersebut perlu adanya tahapan-tahapan didalam pengelolaan

a. Tahap Perencanaan dalam tahap perencanaan yang harus dikerjakanadalah pembentukan

organisasi, menentukan jenis usaha, membuat kerangka usaha. Ketiga hal tersebut harus direncanakan dengan matang dan detail agar badan usaha dapat terwujud dan berkembang dengan baik.

b. Tahap Pengamatan Setelah melakukan tahap perencanaan selanjutnya melakukan pengamatan, pemerintah desa perlu mengamati potensi dan aset desa yang dapat dijadikan usaha BUMDES. Dalam tahapan pengamatan ini sangat penting untuk

benar-benar memahami potensi perkembangan usaha yang akan dijalankan melalui BUMDES tersebut

\section{c.Tahap Penataan dan Seleksi}

Setelah menyelesaikan tahap pengamatan dan mendapatkan data potensi apa saja yang dapat dijadikan usaha BUMDES selanjutnya perlu melakukan penataan. Hal ini 
Rivan Wibowo

Vol. 3 No 1, Februari 2021

ISSN 2657-0203

e-ISSN 2686-0244

penting karena dalam tahap

pengamatan biasanya akan

banyak jenis usaha yang

muncul, maka kemudian

harus dilakukan seleksi dan

penataan yang tepat, sehingga

dapat diperoleh usaha mana

yang paling memiliki potensi

dan dapat dijadikan sebagai

usaha andalan.

d. Tahap Pemeliharaan

Usaha BUMDES yang telah

berjalan harus

memiliki

pemeliharaan yang

baik,.

Pemeliharaan ini meliputi

menyisihkan

keuntungan

untuk keperluan

penyusutan

peralatan, keperluan teknologi

baru dan pemeliharaan umum

dari terjaminnya keamanan

usaha.

e. Tahap Pelaporan

Dalam melakukan usaha apa

pun jenis usahanya harus

memiliki pelaporan usaha, hal

ini berguna sebagai indikator

keberhasilan suatu usaha.

Dalam membuat pelaporan

harus teliti dan adanya transparansi untuk evaluasi dan pertanggung jawaban kepada masyarakat desa.

2. Faktor penghambat dalam pengelolaan Alokasi Dana Desa (ADD) dalam pemberdayaan masyarakat yaitu rendahnya swadaya masyarakat. Dari hasil penelitian, swadaya masyarakat Desa Karangmulya dinilai sangat kurang, padahal swadaya masyarakat merupakan Pendapatan Asli Desa (PADes) yang sah.

Untuk mengatasi hal ini perlu adanya Pengembangan Potensi Desa dikarenakan Desa Karangmulya, Kecamatan Telukjambe Barat, Kabupaten Karawang, Provinsi Jawa Barat, merupakan desa yang termasuk desa swakarya. Kondisi dapat dilihat dari ciri Desa Karangmulya yaitu memiliki tingkat pendidikan yang cukup memadai dengan sarana transportasi seperti jalan untuk menciptakan pergerakan ekonomi dan sosial. Sehingga, jarak sudah tidak lagi menjadi penghalang bagi warganya 
Rivan Wibowo

Vol. 3 No 1, Februari 2021

ISSN 2657-0203

e-ISSN 2686-0244

untuk menciptakan aktivitas sosial lainnya.

3. keterbatasan dalam kegiatan proses pembelajaran yang menuntut adanya keahlian dalam penggunaan teknologi yang bersifat virtual atau penggunaan teknologi media yang bersifat online, bahkan sudah tidak bisa di pungkiri lagi bahwa masih ada siswa dan orang tuanya yang belum bisa beradaptasi terhadap perubahan pola sistem pembelajaran yang memusatkan pada pengoperasian pembelajaran yang bahan ajarnya bersifat online. banyaknya orang tua yang sangat produktif dalam pekerjaan mengelola pertanian, menjadikan salah satu contoh keterhambatan dalam keberlangsungan proses pembelajaran yang bahan ajarnya melalui media online.

Pengunaan gadget yang tidak benar dengan hanya sebatas mengoprasikan hal-hal yang sederhana,tanpa mengetahui bagaimana mengoperasikan teknologi gadget itu dengan benar karena penggunaan nya hanya sebatas huburan untuk anak bukan sebagai media bahan ajar dan bimbingan belajar untuk anak,

Salah satu solusi yang dilakukan terhadap permasalah yang sedang

dihadapi desa tersebut yaitu memberikan rancangan terhadap penyelesaian masalah tersebut dengan cara "Mengoptimalisasikan media online sebagai bahan ajar pada masa pandemi" bagi anak-anak untuk mahir dan bisa mengoperasikan media online sebagai bahan kegiatan proses pengajaran dan pembelajaran dengan baik. Dengan diajarkannya dasardasar optimalisasi media online sebagai bahan ajar pada saat masa pandemic COVID19 ini dengan baik dan benar, maka akan bermanfaat bagi siswa dan guru. Pelatihan tersebut sebagai bentuk pengoptimalisasian media online sebagai bahan ajar yang di koordinasikan dengan para guru di sekolah dasar yang berada di Desa Karangmulya.

4. Permasalahan yang terjadi di Desa Karangmulya dimana Hasil pertanian padi yang tidak stabil sehingga membuat harga jual ikut serta tidak 
Rivan Wibowo

Vol. 3 No 1, Februari 2021

ISSN 2657-0203

e-ISSN 2686-0244

stabil dan berpengaruh terhadap penghasilan masyarakat Adapun solusi untuk mengatasi permasalahan yang telah di uraikan di atas adalah sebagai berikut :

a. Memperbaiki proses pengolahan dan perawatan tanaman padi. Pengolahan tanaman padi dilakukan dengan memulai membajak lahan agar tanah lebih gembur dan membuat menghambat pertumbuhan hama dan penyakit juga dapat membersihkan gulma maupun rumput liar. b. Kemudian memilih bibit yang baik agar dapat menjadi tanaman yang memiliki kualitas baik. Kemudian dengan menggunakan pupuk yang baik agar dapat menambah kesuburan pada tanaman padi sehingga dapat memproduksi tanaman padi yang lebih stabil. Dalam hal ini harus selalu memperhatikan kadar air tercukupi sehingga memberikan nutrisi yang cukup untuk tanaman padi tersebut. Pemerintahan desa juga ikut serta dalam mengatur tercukupnya air untuk pertanian di Desa
Karangmulya. Kegiatan ini dilakukan juga bertujuan untuk menstabilkan pendapatan dari para petani padi yang ada di Desa Karangmulya itu sendiri. Apabila kualitas hasil produksinya sudah baik dan sesuai standar untuk di pasarkan di pasar yang besar maka

hal ini akan memberikan keuntungan baik bagi Pemerintah Desa maupun bagi Petani padi di Desa Karangmulya.

\section{KESIMPULAN DAN SARAN}

Kesimpulan:

1. Dengan potensi sumber dana dan sumberdaya manusia yang ada di desa Karang Mulya maka BUMDes harus dikembangkan lagi minimal mengaktifkan kembali BUMDes Peternakan Desa dan Koperasi Simpan Pinjam.

2. Rendahnya swadaya masyarakat menjadikan faktor penghambat dalam pengelolaan Alokasi Dana Desa (ADD).

3. Pengetahuan anak-anak sekolah dalam mengoperasikan gadget untuk keperluan belajar dimasa pandemic 
COVID-19 masih sangat rendah.

4. Hasil pertanian padi yang tidak stabil sehingga membuat harga jual ikut serta tidak stabil dan berpengaruh terhadap penghasilan masyarakat.

Saran:

1. Perlunya perencanaan dan pengamatan yang baik dalam upaya membangun Badan Usaha Milik Desa (BUMDes) dengan sumber daya manusia yang memadai.

2. Memberikan motivasi kepada masyarat akan pentingnya Alokasi Dana Desa agar kesejahteraan masyarakat semakin meningkat.

3. Mengoptimalisasikan media online sebagai bahan ajar pada masa pandemic

4. Memperbaiki proses pengolahan dan perawatan tanaman padi dan memilih bibit yang bermutu 
Rivan Wibowo

Vol. 3 No 1, Februari 2021

ISSN 2657-0203

e-ISSN 2686-0244

\section{DAFTAR PUSTAKA}

Kamaruddin, S. (.-L.-B. (2019, 03 20). Mengenal BUMDes? APA ituBUMDes?Bagaimana Peranannya? Retrieved from

Berdesa.com:https://wwwkabardesarupe.wordpress.com/2019/03/20/mengenal bumdes- apaitu-bumdes-bagaimana-peranannya/ http://prodeskel.binapemdes.kemendagri.go.id/mdesa/\# diakses 07 September 2020 pukul 09.00

Tata Cara Pembagian dan Penetapan Rincian Dana Desa Setiap Desa Tahun Anggaran 2018www.peraturan.bpk.go.id.

amaliah-diahsavitri.2018.kkn laporan individu didesa blorong kabupaten karanganyar,pelatihan public speaking yang baik yang benar di desa blorong..

http://amalia-diahsavitri.blogspot.com/2019/10laporan-individu-kkn-kuliah-kerja$\underline{\text { nyata.html? } \mathrm{m}=1}$

Asparno Mardjuki. 1994. Pertanian dan Masalahnya. Andi Offset. Yogyakarta http://prodeskel.binapemdes.kemendagri.go.id 
Rivan Wibowo

Vol. 3 No 1, Februari 2021

ISSN 2657-0203

e-ISSN 2686-0244

\section{GAMBAR}

\section{Gambar 1:}

Kantor Kepala Desa

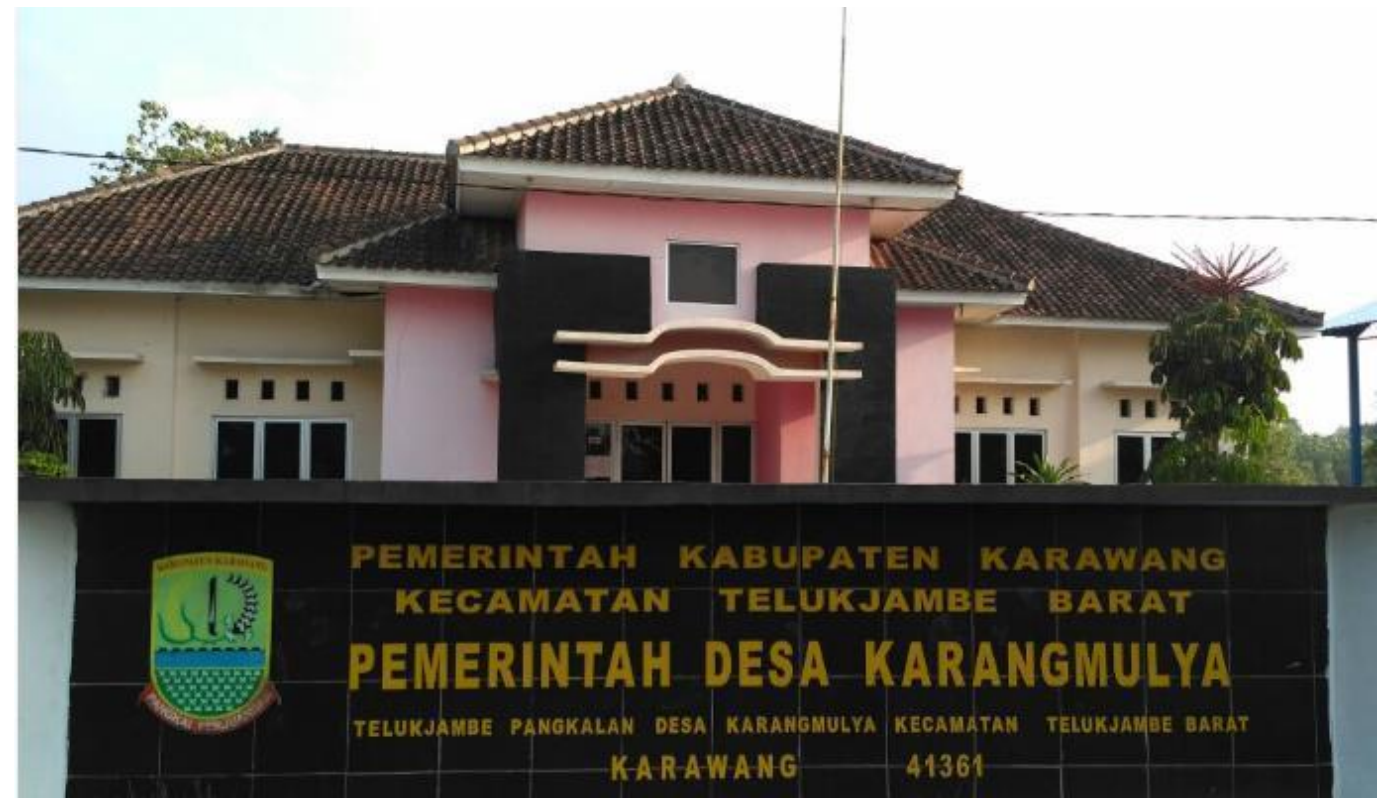

Gambar 2:

Penyerahan surat Tugas KKN dari UBP

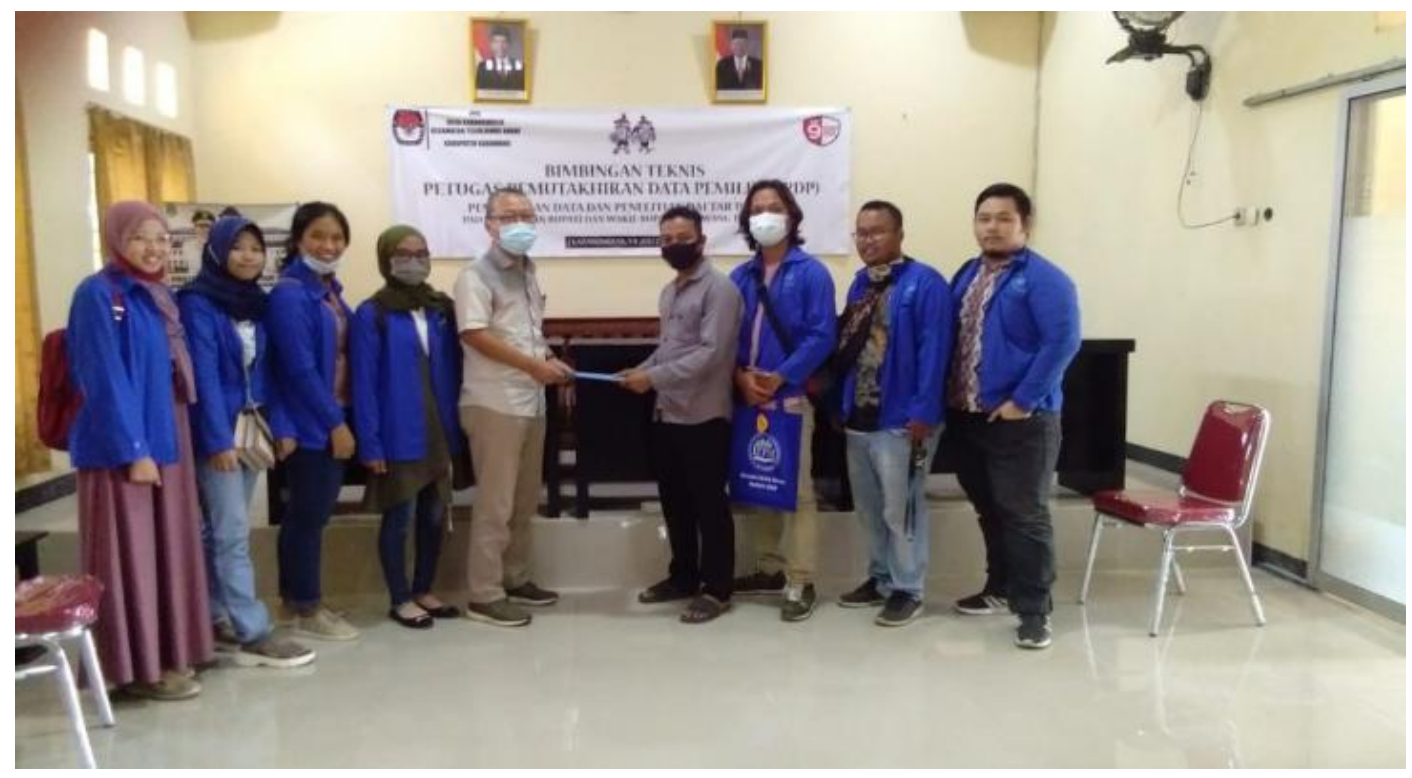


Rivan Wibowo

Vol. 3 No 1, Februari 2021

ISSN 2657-0203

e-ISSN 2686-0244

Gambar 3:

DPL diskusi dengan Kepala Desa

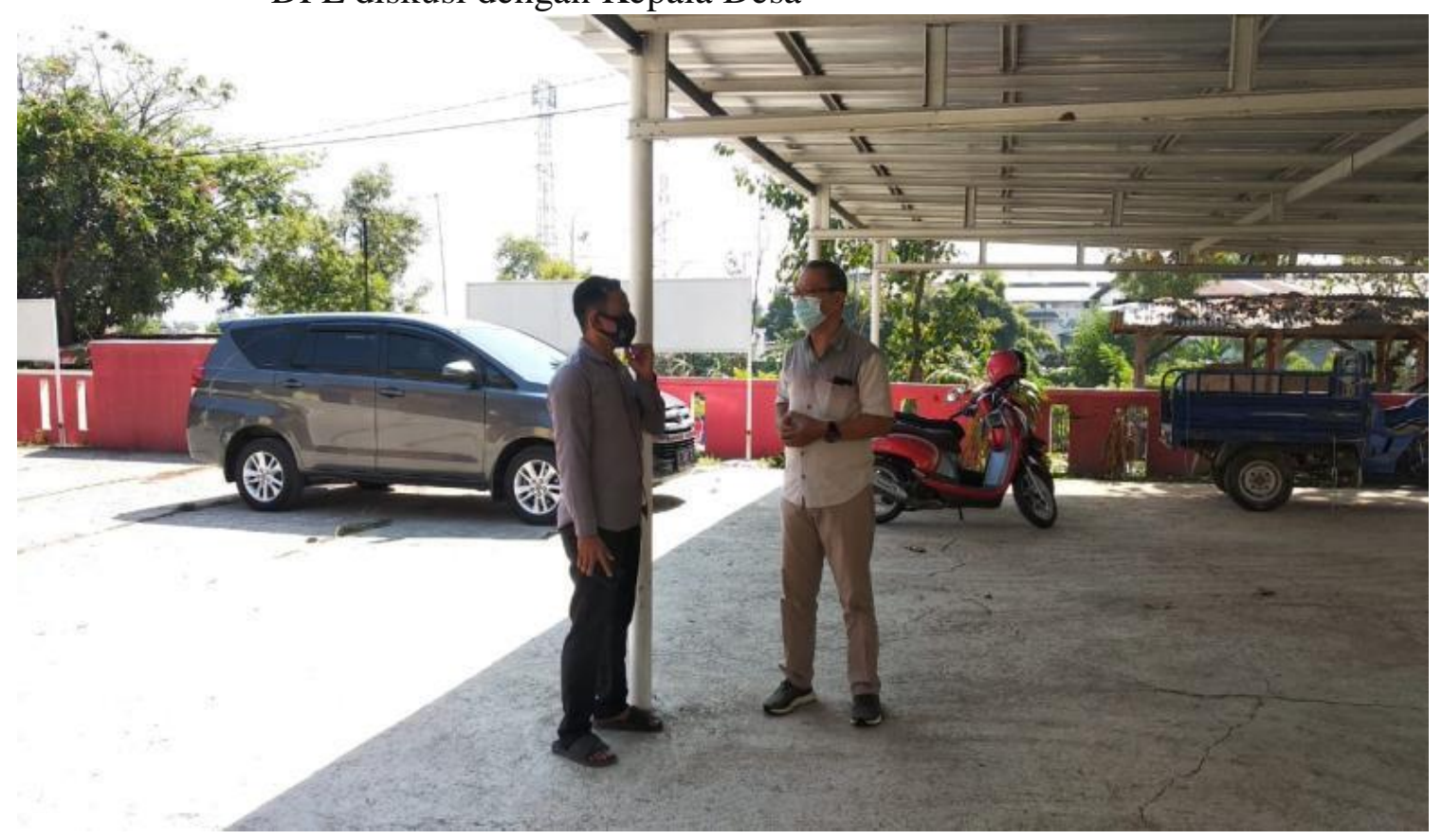

Gambar 4:

Penyerahan Tempat Sampah kepada Kepala Desa

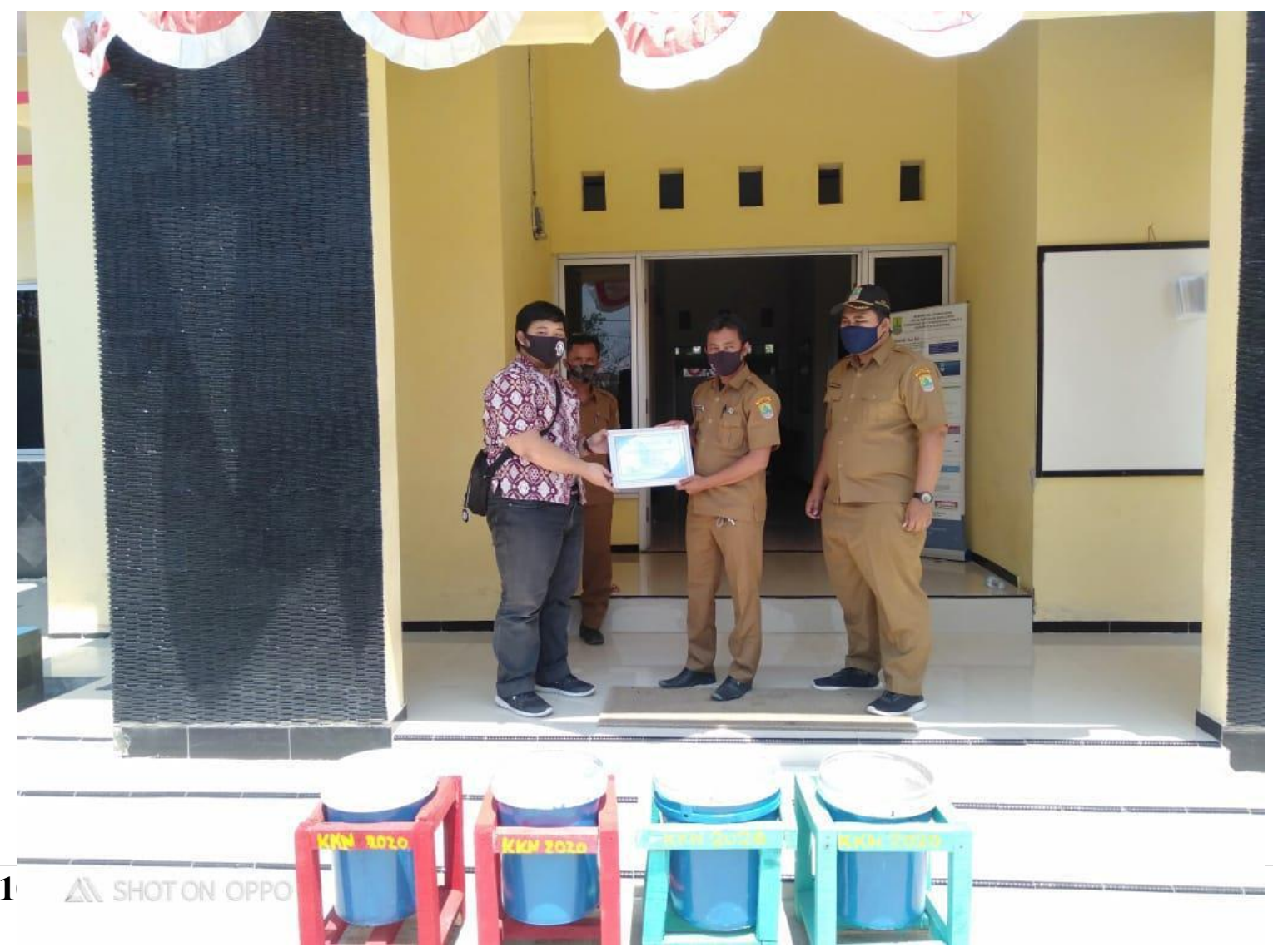

